\title{
NILAI KEARIFAN LOKAL DAN UPAYA PEMERTAHANAN BUDAYA "MARSALAP ARI" DALAM MENJALIN SOLIDARITAS ANTAR SESAMA DI DESA PARINGGONAN SEBAGAI BAHAN AJAR PEMBENTUKAN KARAKTER MAHASISWA
}

\author{
Lili Herawati Parapat ${ }^{1} \&$ Devinna Riskiana Aritonang ${ }^{2}$ \\ Universitas Muhammadiyah Tapanuli Selatan Padangsidimpuan ${ }^{1,2}$ \\ Email: lili.herawati@um-tapsel.ac.id ${ }^{1}$
}

\begin{abstract}
Abstrak
Budaya "Marsalapari" adalah budaya masyarakat yang simbiosis mutualisme. Berdasarkan hasil penelitian budaya "marsalap ari" ini dapat dilihat dari paparan berikut ini. Identitas budaya daerah Paringgonan dengan masyarakat yang membedakan dari budaya lain. Meningkatkan suasana masyarakat yang kondusif. Perekat jiwa solidaritas antar sesama masyarakat alam hidup multikultural, mencegah konflik antar sesasama bermasyarakat. Upaya pemertahanan budaya terhadap perubahan zaman tetap terjaga sehingga dapat dijadikan sebagai bahan ajar dan pembelajaran sekaligus pembentuk karakter manusia. Metode penelitian deskriptif. Analisis data menggunakan dengan cara reduksi, penyajian, dan penarikan kesimpulan. Informan penelitian adalah masyarakat Paringgonan. Berdasarkan hasil penelitian diketahui bahawa upanya masyarakat dalam mempertahankan budaya lokal di Desa paringgonan diketahui $85 \%$ dapat dilihat dari keseluruahn karakter tolong menolong antar sesame masyarakat yang secara bergantian untuk menyelesaikan pekerjaan bersama, disawah dan diladang. Kerukunan, kerjasama dalam masyarakan terjalin dan dapat dibertahan. Dengan demikian "Nilai Kearifan Lokal Dan Upaya Pemertahanan Budaya "Marsalap Ari" Dalam Menjalin Solidaritas Antar Sesama dapat dijadikan Sebagai Bahan Ajar Pembentukan Karakter Mahasiswa.
\end{abstract}

Kata kunci: budaya, solidaritas, simbiosis mutualisme.

\begin{abstract}
"Marsalapari" is a culture of society that has symbiotic mutualism. Based on the results of research on the culture of "marsalapari" can be seen from the following description; The cultural identity of the Paringgonan region with the community is different from other cultures, improving conducive community atmosphere, the boundaries to the spirit of solidarity between people living in multicultural life, opposing conflicts between communities. The efforts to maintain culture against changing times can still be done as teaching and learning materials as well as forming human character. The method used is Descriptive. Data analysis used reduction, presentation, and drawing conclusions. The research informant is the Paringgonan community. Based on the result, it is known that the community in maintaining local culture in Paringgonan Village is recognized $85 \%$ can be seen from the whole character. Harmony, cooperation in society, established and can be maintained. Thus "Local Wisdom Values and Cultural Retention Efforts" Marsalap Ari "in Establishing Inter-Fellow Solidarity can be used as Teaching Materials for Student Character Building.
\end{abstract}

Keywords: culture, solidarity, mutualism symbiosis.

\section{PENDAHULUAN}

Nilai dalam setiap kearifan lokal khususnya budaya dapat dijadikan sebagai bahan ajar pembentukan karakter manusia. Berkenaan dengan hal tersebut dapat dilihat dari beberapa hasil penelitian budaya yang sebelumnya sudah diteliti dari berbagai daerah. dapat dilihat dari hasil penelitian Ufie (2016) tentang Mengonstruksi Nilai-nilai Kearifan Lokal (Local Wisdom) dalam Pembelajaran 
Muatan Lokal sebagai Upaya Memperkokoh Kohesi Sosial (Studi Deskriptif Budaya Niolilieta Masyarakat Adat Pulau Wetang Kabupaten Maluku Barat Daya, Propinsi Maluku) bahwa bangsa Indonesia memiliki budaya lokal yang sarat dengan nilai- nilai sosial, moral harus terus dikembangkan dan dilestarikan sehingga generasi muda mampu hidup sesuai dengan nilai-nilai budaya dimaksud, mereka mampu mempertahankan relasirelasi sosial anatar sesama tidak termakan arus modernisasi yang terus menggeliat. Kemudian hasil penelitian Abdulkarim, dkk. (2016) menyiimpulkan bahwa "Bangsa yang besar adalah bangsa yang memiliki karakter berasal dari nilai-nilai budaya masyarakatnya. Serta Nilai kearifan lokal mempunyai relevansi dengan pembangunan karakter bangsa. Upaya untuk menggali nilai kearifan lokal merupakan langkah yang strategis dalam pembangunan karakter bangsa. Abdulkarim, dkk. (2016) menjelaskan bahwa Bangsa yang besar adalah bangsa yang memiliki karakter berasal dari nilainilai budaya masyarakatnya. Nilai kearifan lokal mempunyai relevansi dengan pembangunan karakter bangsa. Upaya dalam menggali nilai kearifan lokal merupakan langkah yang strategis dalam pembangunan karakter bangsa. Kearifan lokal merupakan nilai yang diyakini dalam suatu masyarakat menjadi acuan bertingkah laku dalam kehidupan seharihari. Hal tersebut dapat ditemui dalam semboyan, konsep, pepatah, nyanyian, kitab-kitab kuno, tradisi, dan cara masyarakat lokal memenuhi kebutuhan hidupnya.

Efferin (2015) tentang akuntansi, spiritualitas dan kearifan lokal di Bali dapat dilihat bahwa kearifan local \& budaya itu penting dapat dibuktikan dari "Berbagai penelitian tentang Tri Hita Karana dan kearifan lokal di era Bali kuno telah memberikan gambaran awal tentang bagaimana modal sosial dapat membawa kesadaran dalam hidup bermasyarakat. Tentunya masih banyak lagi kearifan lokal di bumi nusantara ini yang berang-kat dari pengalaman sejarah kita bersama. Abubakar (2016:20) menjelaskan bahwa budaya merupakan ekspresi cipta, karya, dan karsa manusia (dalam masyarakat tertentu) yang mengandung nilai-nilai religiusitas, filosofis,localwisdom).

Pemertahanan budaya yang memiliki keriteria dalam pembentukan karakter perlu dilestarikan dan dijadikan sebagai bahan ajar. Kemudian lemahnya karaketer mahasiswa dalam bidang sosial, kerja sama, tanggung jawab, komunikatif, jujur, torelan, disiplin, kreatip, dan lain sebagainya yang dipengaruhi oleh perkembangan zaman modren. Sehingga banyak mahasiswa yang bingung dan tidak tahu tentang budaya ataupun kearifan lokal ynag terdapat di daerahnya masing-masing, yang didalamnya banyak nilai pendidikan, pendidikan karakter. Salah satunya adalah budaya "Marsalap Ari" di desa Paringgonan Kecamatan Ulu Barumun, Kabupaten Padang Lawas yang memiliki banyak nilai yang dapat dijadikan sebagai referen dan bahan ajar dalam membentuk karakter manusia.

Berdasarkan hasi penelitian latar belakang permasalahan yang sebelumnya tentang penelitian budaya dapat disimpulkan bahwa bangsa yang memiliki karakter berasal dari nilai-nilai budaya masyarakat. Kemudian untuk membentuk karakter mahasiswa dapat diambil dari nilai kearifan lokal. Karena langkah strategis untuk pembentukan karakter mahasiswa harus digalih dari nilai kearifan lokal. Berkenaan dengan hal tersebut peneliti mengajukan penelitian tentang "nilai kearifan lokal dan upaya Pemertahanan budaya "marsalap ari" yang mengajarkan karakter sosial bersahabat/komunikatif dan bertanggung jawab yang dijadikan sebagai bahan ajar pembentuk karakter.

Provinsi Sumatera Utara kabupaten Padang Lawas Kecamatan Ulu Barumun Desa Paringgonan memiliki banyak budaya yang masih dibudayakan sampai sekarang. 


\section{METODE}

Tempat yang menjadi objek penelitian ini adalah didesa paringgonan Kecamatan Ulu Barumun Kabupaten Padang Lawas.

Metode penelitian yang digunakan adalah deskriptif kualitatif menggunakan studi pendahuluan ke lokasi penelitian. Pengumpulan data dilakukan dalam dua tahap. Tahap pertama, tahap perekaman. Hasil rekaman di transkripsi (alih aksara) akan ditransliterasi (alih bahasa) dari bahasa daerah Paringgonan ke dalam bahasa Indonesia. Tahap kedua, pengumpulan data tentang lingkungan penceritaan. Data tentang lingkungan penceritaan dikumpulkan melalui teknik pencatatan, pengamatan, dan wawancara tentang upaya pemertahanan budaya "marsalap ari". Sebelum dianalisis, data diklasifikasikan dan diinventarisasikan ke dalam tabel. Teknik pengumpulan data pada penelitian ini adalah sebagai berikut.

1. Studi pendahuluan

2. Mempersiapkan bahan dan alat penelitian Melaksanakan penelitian dengan menggunakan bahan dan alat penelitian.

3. Melakukan wawancara dengan informan (masyarakat Paringgonan).

4. Menginterpretasikan hasil wawancara kedalam bentuk tulisan.

5. Mengidentifikasi dan menganalisis hasil.

6. Membuat simpulan dan saran penelitian

Analisis data di lakukan dnegan cara sebagai berikut.

1. Reduksi data

2. Penyajian data

3. Interpretasi hasil

4. Penarikan Simpulan Akhir

\section{HASIL DAN PEMBAHASAN}

Berdasarkan hasil penelitian pada sebagian masyarakat Paringgonan bahwa: Hanifah Parapat umur 25 Tahun Menyampaikan bahwa upaya pemertahanan budaya terhadap perubahan zaman tetap terjaga antara orang tua dengan orang tua, orang tua dengan anak, anak dengan adnak, saudara dengan saudara lainnya. Irhamuddin umur 35 Tahun juga menjelaskan bahwa "Marsalap Ari" adalah satu budaya yang memberikan banyak manfaat bagi masyarakat. Nilai sosial yang tinggi, tanggung jawab, tolong menolong tanpa mengharapkan imbalan rupiah. Lanna Sari Hasibuan umur 41 Tahun beliau adalah masyarakt desa Paringgonan Kecamatan Ulu Barumun Kabupaten padang Lawas menjelaskan bahwa marsalap ari adalah salah satu cara yang dikerjakan oleh sebagian kalangan untuk tetap menjalin rasa kekeluargaan dan saling membantu dengan cara bergantian. Karena "marsalap ari" tidak mengharapkan upah/gaji. Irmadani umur 32 tahun menjelaskan bahwa "marsalap ari" adalah menyelesaikan pekerjaan dengan sanak famili maupun dengan orang lain. Tanpa memberi imbalan berupa uang/gaji. Tetapi pekerjaan suka rela, dan saling bergantian. Tujuan "marsalap ari" adalah satu budaya yang emnumbuhkan dan dapat meningkatkan rasa tanggung jawab dan gotong-ronyong dan kerjasama. Selain itu "marsalap ari" juga bertujuan untuk menjalin hubungan kekeluargaan agar tetap saling kenal antara famili yang dekat maupun jauh.

Berdasarkan hasil penelitian Pelasanaan "Marsalapari" dilaksanakan secara suka rela dan bergantian. Situasi ini pada dasarnya dilaksanakan pada saat seperti manyabii (memanen padi) dan manyuan eme (menanam padi), marbabo (mencabuti rumput padi). 'Marsalap ari' merupakan salah satu budaya masyarakat Paringgonan yang memiliki nilai yang dapat dijadikan sebagai bahan ajar pembentukan karakter manusia, khusunya mahasiswa.

\section{KESIMPULAN}

Berdasarkan hasil penelitian budaya "marsalap ari" ini dapat dilihat dari paparan berikut ini. Identitas budaya daerah Paringgonan dengan masyarakat 
yang membedakan dari budaya lain. Meningkatkan suasana masyarakat yang kondusif. Perekat jiwa solidaritas antar sesama masyarakat alam hidup multikultural, mencegah konflik antar sesasama bermasyarakat. Upaya pemertahanan budaya terhadap perubahan zaman tetap terjaga sehingga dapat dijadikan sebagai bahan ajar dan pembelajaran sekaligus pembentuk karakter manusia. Metode penelitian deskriptif. Analisis data menggunakan dengan cara reduksi, penyajian, dan penarikan kesimpulan. Informan penelitian adalah masyarakat Paringgonan. Berdasarkan hasil penelitian diketahui bahawa upanya masyarakat dalam mempertahankan budaya lokal di Desa paringgonan diketahui $85 \%$ dapat dilihat dari keseluruahn karakter tolong menolong antar sesame masyarakat yang secara bergantian untuk menyelesaikan pekerjaan bersama, disawah dan diladang. Kerukunan, kerjasama dalam masyarakan terjalin dan dapat dibertahan.

\section{DAFTAR PUSTAKA}

Abdulkarim, dkk. Nilai Budaya Tradisi Dieng Culture Festival sebagai Kearifan Lokal untuk Membangun Karakter Bangsa. Journal of Urban Society's Art Volume 3 Nomor 2, Oktober 2016: 82-9. http://journal.isi.ac.id/index.php/JOU SA/article/view/1477. Diakses pada hari Jumat 31 Agustus 2018.

Abubakar, Fauzi. (2016). Interaksi Islam Dengan Budaya Lokal Dalam Tradisi Khanduri Maulod Pada Masyarakat Aceh. Jurnal Akademika, Vol 21. No. 01 Januari-Juni 2016.

Alam, Sutan Tinggi barani Perkasa. (2017). Surat Tumbaga Holing. Medan: PT. Mitra
Efferin, Sujoko. Akuntansi,Spiritualitas Dan Kearifan Lokal: Beberapa Agenda Penelitian Kritis. Jurnal Akuntansi Multiparadigma JAMAL. Volume 6 Nomor 3, 2015. http://jamal.ub.ac.id/index.php/jamal/a rticle/view/366/pdf. Diakses pada hari Jumat 31 Agustus 2018.

Harysakti, Ave dkk. Elemen-Elemen Pendorong Kearifan Lokal Pada Arsitektur Nusantara. Jurnal Perspektif Arsitektur Volume 9 / No.1, Juli

2014.www.jurnalperspektifarsitektur.c om/download/(Jurnal\%20PA\%20Vol. 09\%20No.01\%202014)-ELEMENELEMEN-PENDORONGKEARIFAN-LOKAL-PADAARSITEKTUR-NUSANTARA.pdf. Diakses pada hari Jum'at 31 Agustus 2018.

Nisa, Hany Uswatun \& Supriyanto, Teguh. 2016. Pengembangan Bahan Ajar Membaca Sastra Legenda Bermuatan Kearifan Lokal Berbahasa Jawa. Seloka: Jurnal Pendidikan Bahasa dan Sastra Indonesia. Vol. 5 No. 2. Tahun 2016.

Ufie. Mengonstruksi Nilai-nilai Kearifan Lokal (Local Wisdom) dalam Pembelajaran Muatan Lokal sebagai Upaya Memperkokoh Kohesi Sosial (Studi Deskriptif Budaya Niolilieta Masyarakat Adat Pulau Wetang Kabupaten Maluku Barat Daya, Propinsi Maluku). Pada Jurnal pendidikan dan pembelajaran, Volume 23, Nomor 2, Oktober 2016. http://journal.um.ac.id/index.php/pend idikan-dan-

pembelajaran/article/view/10157/4844

. Diakses pada hari Jumat 31 Agustus 2018.

Yaumi, Muhammad. (2011). Pendidikan Karakter. Jakarta: Kencana. 